\title{
A PRIMER OF VESTIBULAR FUNCTION, SPATIAL DISORIENTATION, AND MOTION SICKNESS
}

KENT K. GILLINGHAM, Captain, USAF, MC

Review 4-66

USAF School of Aerospace Medicine Aerospace Medical Division (AFSC)

Brooks Air Force Base, Texas

June 1966 